\title{
The Presence of Pathogenic Leptospira sp. in Water Bodies in Klaten District by Lintang Saraswati
}




\title{
The Presence of Pathogenic Leptospira sp. in Water Bodies in Klaten District
}

\author{
Novia Tri Astuti ${ }^{1}$, Mateus Sakundarno Adi ${ }^{2}$, Yuliani Setyaningsih ${ }^{3}$, Martini $^{4}$, Lintang Dian Saraswati ${ }^{4}$ \\ ${ }^{\prime}$ Research and Development Unit, Banjarnegara, Central Java, Indonesia, 53415; ${ }^{2}$ Master Program of \\ Epidemiology, School of Postgraduate Studies Diponegoro University, Semarang, Indonesia; ${ }^{3}$ Master \\ Program of Health Promotion, Faculty of Public Health, Diponegoro University, Semarang, Indonesia; \\ ${ }^{4}$ Department Epidemiology and Tropical Diseases, Faculty of Public Health, Diponegoro University, \\ Semarang, Indonesia, 50275
}

\begin{abstract}
Leptospirosis is a health problem in Indonesia. In the year 2016 cases of leptospi 4 sis in Klaten reported death rate $15.38 \%$. The presence of Leptospira 4 cteria in the body of water plays an important role in the transmission of leptospirosis. This study aims to determine the presence of Leptospira bacteria in water bodies in Klaten Regency. This research is descriptive research with survey method using cross sectional design. The sample was 100 water samples from wells, rivers and paddy fields in endemic and non endemic areas of Leptospirosis. Polymerase Chain Reaction examination there were 6 positive water samples of rpoB leptospira gene on well water (6.7\%), irrigation channel (6.7\%) and paddy field (5\%). Leptospira is found at temperatures ranging from $24-31^{\circ} \mathrm{C}, \mathrm{pH} 6.8-7.5$ and dissolved oxygen $4-12 \mathrm{ppm}$.
\end{abstract}

Keywords: Leptospira sp., water bodies, irrigation channels, bacteria

\section{INTRODUCTION}

Leptospirosis is one of th/3 most widespread bacterial zoonoses in the world. ${ }^{1}$ Leptospirosis, caused by pathogenic spirochetes belonging to the genus Leptospira, is a zoonosis that has important impacts on human and animal he 6 th worldwide. ${ }^{2}$ Transmission to mammals occurs via direct contact with leptospirainfected urine or tissues or indirectly through contact with contaminated soil or water. Although infection may take place through unbroken skin after prolonged immersion, Leptospira sp. usually gain entry to the host via abrasions or cuts in the skin or through exposed mucosae (eyes, nose, etc.). ${ }^{3}$ Soil,${ }^{4.5}$ mud, ${ }^{6}$ and surface waters contaminated with urine from chronicallyinfected reservoir hosts remain important sources of human leptospirosis transmission worldwide..$^{7-9}$

\section{Corresponding Author:}

Lintang Dian Saraswati

Department Epidemiology and Tropical Diseases,

Public Health Faculty, Diponegoro University,

J1. Prof. Sudarto, SH,Tembalang, Semarang, 50275

Email: lintang.saraswati@live.undip.ac.id
Based on data from the Central Java Provincial Health Office, cases of leptospirosis in Central Java have increased cases from 2012 to 2014. In 2015 cases in Central Java declined from the previous year, but the Case Fatality Rate (CFR) stagnated ${ }^{10}$ Klaten District is one of the endemic areas of leptospirosis. Leptospirosis in Klaten District occurs every year for the last five years. In 2016 reported 39 patients with 6 deaths (CFR $=15.38 \%$ ). The case spread sporadically, not clustered in one place. Leptospirosis in Klaten regency was dominated by patients with occupation as farmer and laborer (79.49\%) and had wound history (87.18\%). ${ }^{11}$

The high prevalence rate of Leptospirosis in tropical and subtropical climates can be attributed to adverse environmental conditions that allow the environment to be a suitable place to live and develop of Leptospira bacteria. $^{6.12}$ Outbreaks of leptospirosis have been associated with common water events such as rural and urban flooding, swimming, and other water sports as well as occupational exposure involved predominantly with farming and drinking contaminated water. ${ }^{13,14}$ The presence of Leptospira sp. bacteria in the body of water plays an important role in the transmission of 


\section{5}

leptospirosis. The purpose of this study was to determine the presence of Leptospira sp. bacteria in water bodies. Tested using PCR (Polymerase Chain Reaction) method to determine the presence of Leptopsira sp. bacteria in water bodies with high sensitivity reaches $90-100 \%$.

\section{METHOD}

The design of this study is cross sectional conducted by survey method. Sample in this research is water well, irrigation channels and paddy field in case area and free of leptospirosis in Klaten District. The water sample is determined based on the proportion estimation formula from Lemeshow to obtain 100 water samples taken by puposive. Water samples taken from wells are commonly used by respodents, irrigation channels used by respondents to cleanse themselves and paddy fields where respondents work. Each water sample was taken with a volume of $150 \mathrm{ml}$ placed in a dark glass bottle. Water samples are stored at $4^{\circ} \mathrm{C}$ and processed within 24 hours. ${ }^{15}$

Water samples taken measured temperature, $\mathrm{pH}$ and dissolved oxygen. Temperature measurements are carried out with a water thermometer that is by dipping the thermometer into water and allowing for 2-5 minutes until the thermometer shows a stable value. Then record the thermometer scale reading without lifting the thermometer in water. ${ }^{16}$ The $\mathrm{pH}$ measurement is done by dipping the electrode into a water sample until the $\mathrm{pH}$ meter indicates a fixed reading. Then record the reading of the scale or number on the view of $\mathrm{pH}$ meter. ${ }^{17}$ Dissolved Oxygen measurements using Dissolved Oxygen meter in accordance with WalkLAB Digital Dissolved Oxygen meter. ${ }^{18}$

Each water sample was filtered with one nitrocellulose membrane (Milipore) whose pore size was $0.22 \mu \mathrm{m}$. Next the membrane is cut into small pieces and inserted into a microsentrifuge tube. The next stage is the DNA isolation of the niroselulose membrane used to filter the water sample. The DNA isolation was performed using the Genomic DNA Mini Kit isolation kit (Geneaid). The isolation stages are performed according to the procedures listed in the kit manual.

The Polymerase Chain Reaction (PCR) process performed on DNA samples was obtained using primers; rpoB-F-CCTCATGGGTTCACAATATCA and RpoBR-CGCATCCTCRAAGTTGTAWCCTT using Go Taq Green Master Mix (Promega). ${ }^{19}$ PCR Stages were as follows: predenatur 2 on $94^{\circ} \mathrm{C}$ for 2 minute, followed by 40 amplification cycles consisting of denaturation at $94^{\circ} \mathrm{C}$ for $30 \mathrm{~s}$, annealing at $55^{\circ} \mathrm{C}$ for $1 \mathrm{~min}$, extension at $72^{\circ} \mathrm{C}$ for $1 \mathrm{~min}$ followed by a final extension for 20 min at $72^{\circ} \mathrm{C}$. Analysis of PCR results was performed with electrophoresis using agarose $1.5 \%$ at 100 volts for $15 \mathrm{~min}$. Specific DNA visualizations were performed using UV transilluminators. Positive samples when electrophoresis results showed that the DNA bands were in the $600 \mathrm{bp}$ position.

\section{RESULTS AND DISCUSSIONS}

One hundred water samples consist of well water, irrigation channels and paddy fields coming from subdistricts where leptospirosis cases occur every year, subdistricts almost every year occurs leptospirosis cases and sub-district without leptospirosis in Klaten District. Six positive water samples of rpoB gene were obtained from two wells, two rivers and two rice fields. This indicates that the water bodies are contaminated by the Leptospira sp. from infected animals. Prevalence of Leptospira sp. in water samples are tabulated in Table 1.

Table 1: Results of water sampling and Leptospira sp detection based on Leptospira rpoB gene detection. $(\mathrm{n}=100)$

\begin{tabular}{|c|c|c|c|c|}
\hline $\begin{array}{c}\text { Distribution } \\
\text { area }\end{array}$ & $\begin{array}{c}\text { Water } \\
\text { sources }\end{array}$ & $\begin{array}{c}\text { Total } \\
\text { sample }\end{array}$ & $\begin{array}{l}\text { Positive } \\
\text { sample }\end{array}$ & $\begin{array}{l}\text { Percentage } \\
\text { of positive } \\
\text { sample }(\%)\end{array}$ \\
\hline \multirow{3}{*}{$\begin{array}{c}\text { Sub-district } \\
\text { with cases } \\
\text { occurs every } \\
\text { years }\end{array}$} & wells & 11 & 0 & 0.0 \\
\hline & $\begin{array}{l}\text { irrigation } \\
\text { channels }\end{array}$ & 11 & 2 & 18.18 \\
\hline & $\begin{array}{l}\text { paddy } \\
\text { fields }\end{array}$ & 15 & 1 & 6.67 \\
\hline \multirow{3}{*}{$\begin{array}{c}\text { Sub-district } \\
\text { with cases } \\
\text { occurs } \\
\text { almost every } \\
\text { years }\end{array}$} & wells & 11 & 2 & 18.18 \\
\hline & $\begin{array}{r}\text { irrigation } \\
\text { channels }\end{array}$ & 11 & 0 & 0.0 \\
\hline & $\begin{array}{l}\text { paddy } \\
\text { fields }\end{array}$ & 15 & 1 & 6.67 \\
\hline \multirow{3}{*}{$\begin{array}{l}\text { Sub-district } \\
\text { without } \\
\text { cases }\end{array}$} & wells & 8 & 0 & 0.0 \\
\hline & $\begin{array}{l}\text { irrigation } \\
\text { channels }\end{array}$ & 8 & 0 & 0.0 \\
\hline & \begin{tabular}{|c|} 
paddy \\
fields \\
\end{tabular} & 10 & 0 & 0.0 \\
\hline
\end{tabular}

Our study revealed that Leptospira bacteria is found in sub-district with cases occurs every years and sub-district with cases occurs almost every years. In sub-districts with cases ocuurs every year, Leptospira bacteria found in irrigation channels (18.18\%) and paddy fields $(6.67 \%)$. While in sub-districts with cases occurs almost every year, Leptospira sp. are 
found in wells (18.18\%) and paddy fields (6.67\%). The bacteria were found in irrigation channels, one of the positive irrigation channels found rats holes, water in the irrigation channels was relatively stagnant. The presence of rats around the river can contaminate the water in the irrigation channels. Leptopsires survive weeks or months in moist and warm soil, stagnant water at neutral or slightly $\mathrm{pH}^{20.21}$ And based on observation on two positive wells of Leptopsira, the floor around the well is made from soil, not segmented with cement.
Wells are easily contaminated through floors which is not made with water resistant material. ${ }^{22}$ Leptospira bacteria contamination in the paddy fields is caused, a paddy field is a place for the availability of food for rats. And the soil in the paddy fields is wet. It is suitable for Leptospira sp. to survive for long period of time. Besides that, there were water puddles in the rice field allows for Leptospira sp. spread the contaminated urine in the soil. Previous study revealed that Leptospira serovar Harjo has higher survival rate in moist soil at $\mathrm{pH} 6.9-7.4{ }^{23}$

Table.2: Results of water sampling and Leptospira sp. detection based on Leptospira rpoB gene detection

$(\mathrm{n}=100)$

\begin{tabular}{|c|c|c|c|c|c|}
\hline Distribution area & & Sampling code & ${ }^{\circ} \mathbf{C}$ & $\mathbf{p H}$ & DO \\
\hline \multirow{2}{*}{$\begin{array}{c}\text { Sub-district with cases } \\
\text { occurs every years }\end{array}$} & Cawas irrigation channels 1 & CB2 & 30 & 6,9 & 12 \\
\cline { 2 - 6 } & Cawas irrigation channels 2 & CB3 & 24 & 6,8 & 6,9 \\
\cline { 2 - 6 } & Trucuk paddy fields & TC4 & 28 & 7,4 & 9,2 \\
\hline \multirow{2}{*}{$\begin{array}{c}\text { Sub-district with cases } \\
\text { occurs almost every years }\end{array}$} & Kebonarum paddy fields & KBC3 & 31 & 6,8 & 8,7 \\
\cline { 2 - 6 } & Klaten Selatan 1 well & KSA1 & 28 & 7,5 & 4 \\
\cline { 2 - 6 } & Klaten Selatan 2 well & KSA2 & 28 & 7,2 & 5,7 \\
\hline
\end{tabular}

Temperature was important factor for the survival of Letopsires in the nature. ${ }^{21}$ Leptospires are obligate aerobes with an optimum growth temperature of 28 to $30^{\circ} \mathrm{C} .{ }^{24}$ In this study Leptospira sp. was found at a temperature of $24-31^{\circ} \mathrm{C}$, pH $6.8-7.4$ and DO $4-12 \mathrm{ppm}$. These results show the ability of Leptospira sp. to survive in a variety of environmental conditions. Our results are consistent with the theory that the ability to survive Leptospira sp. in the environment is affected by variations in soil and water conditions in contaminated areas. ${ }^{25}$ Well water and paddy fields in the leptospirosis case areas have more optimal temperatures compared to leptopsirosisfree areas. Temperature is influenced by external factors such as weather, wind and currents. In addition, water temperature variations are caused by natural processes such as biochemistry, through organisms that produce heat (endothermic and exothermic reactions) and microbiological processes (geothermal sources). ${ }^{26}$ Optimal temperature makes Leptospira sp. survive last longer. The previous study found that The leptospires can survive for 10 months in adverse condition $\left(4^{\circ} \mathrm{C}\right)$ and up to 20 months when stored at $30^{\circ} \mathrm{C} .{ }^{27}$ Length of life of Leptospira bacteria in water can be affected by water $\mathrm{pH}$. Optimum growth of Leptospira bacteria occurred in the range of $\mathrm{pH} 7.2-7.6 .{ }^{28}$ The result of examination found the existence of Leptospira bacteria at relatively acidic $\mathrm{pH}$ that is $\mathrm{pH}$ 6.8-6.9. This research is in line with research conducted by Benacer in Malaysia, that
Leptospira bacteria found in water with acidic $\mathrm{pH}$ that is 5.77-6.63. ${ }^{18}$ State of environmental conditions that are not suitable for breeding bacteria Leptospira can cause bacteria are inhibited growth even become die. ${ }^{4}$ Based on research found Leptospira The oxygen concentration is influenced by many factors 17cluding water temperature, photosynthesis rate, turbidity and water depth, degree of water turbulence or wave action, and the amount of oxygen used by respiration and decay of organic matter. The oxygen concentration is the limiting factor of growth.

\section{CONCLUSIONS}

Leptospira sp. can live at temperatures and $\mathrm{pH}$ beyond the optimal limit for its growth. From 100 water samples examined, six samples found positive rpoB gene from well water samples $(6.7 \%)$, irrigation channels $(6.7 \%)$ and paddy fields $(5 \%)$.

\section{ACKNOWLEDGEMENTS}

All the authors thanks to Diponegoro University for research funding. We also thanks to the study participant, District Health Office of Klaten, Health Research and Development Unit, Banjarnegara, for their cooperation in facilitating our study. 
Conflict of Interest: The author reports no conflicts of interest in this work.

Ethical Clearance: Ethical clearance was obtained from Ethic Commission of Health Research, Faculty of Public Health UNDIP (123/EC/FKM/2017). All subjects signed informed consent to join the study.

\section{REFERENCES}

1. Adler B. Pathogenesis of leptospirosis: Cellular and molecular aspects. Veterinary Microbiology. 2014.

2. Bharti AR, Nally JE, Ricaldi JN, Matthias MA, Diaz MM, Lovett MA, et al. Leptospirosis: a zoonotic disease of global importance. Lancet Infect Dis [Internet]. 2003 Dec [cited 2016 Sep 11];3(12):757-71. Available from: http://linkinghub.elsevier.com/retrieve/pii/ S1473309903008302

3. Collen L Lau, Smythe LD, Craig SB, Phillip W. Climate change, flooding, urbanisation and leptospirosis: fueling the fire? Trans R Soc Trop Med Hyg. 2010;104(10):631-8.

4. Benacer D, Woh PY, Mohd Zain SN, Amran F, Thong KL. Pathogenic and saprophytic Leptospira species in water and soils from selected urban sites in peninsular Malaysia. Microbes Environ [Internet]. 2013 [cited 2017 Jul 10];28(1):135-40. Available from: http://www.ncbi.nlm.nih.gov/ pubmed $/ 23363618$

5. Benacer D, Thong KL, Verasahib K Bin, Galloway RL, Hartskeerl RA, Lewis JW, et al. Human Leptospirosis in Malaysia: Reviewing the Challenges After 8 Decades (1925-2012). Asia Pac J Public Health [Internet]. 2016 May [cited 2016 Sep 2];28(4):290-302. Available from: http://www.ncbi.nlm.nih.gov/pubmed/27044535

6. Johnson MAS, Smith H, Joeph P, Gilman RH, Bautista CT, Campos KJ, et al. Environmental exposure and leptospirosis, Peru. Emerg Infect Dis [Internet]. 2004 Jun [cited 2016 Sep 11];10(6):1016-22. Available from: http://www. ncbi.nlm.nih.gov/pubmed/15207052

7. Hunter PR. Climate change and waterborne and vector-borne disease. J Appl Microbiol [Internet].
2003 [cited 2016 Sep 11];94 Suppl:37S-46S. Available from: http://www.ncbi.nlm.nih.gov/ pubmed/12675935

8. Monahan AM, Miller IS, Nally JE. Leptospirosis: risks during recreational activities. J Appl Microbiol [Internet]. 2009 Sep [cited 2017 Jul 10];107(3):707-16. Available from: http://www. ncbi.nlm.nih.gov/pubmed/19302325

9. Sakundarno M, Bertolatti D, Maycock B, Spickett J, Dhaliwal S. Risk factors for leptospirosis infection in humans and implications for public health intervention in Indonesia and the AsiaPacific region. Asia Pac J Public Health [Internet]. 2014 Jan [cited 2016 Sep 2];26(1):15-32. Available from: http://www.ncbi.nlm.nih.gov/ pubmed/24097928

10. Dinas Kesehatan Provinsi Jawa Tengah. Buku Saku Kesehatan Tahun 2015. Semarang; 2015.

11. Dinas Kesehatan Kabupaten Klaten. Surveilans Leptospirosis Kabupaten Klaten 2013-2016. 2016.

12. Reis RB, Ribeiro GS, Felzemburgh RDM, Santana FS, Mohr S, Melendez AXTO, et al. Impact of environment and social gradient on Leptospira infection in urban slums. PLoS Negl Trop Dis [Internet]. 2008 [cited 2016 Sep 11];2(4):e228. Available from: http://www.ncbi.nlm.nih.gov/ pubmed/18431445

13. Morgan J, Bornstein SL, Karpati AM, Bruce $\mathrm{M}$, Bolin CA, Austin CC, et al. Outbreak of Leptospirosis among Triathlon Participants and Community Residents in Springfield, Illinois, 1998. Clin Infect Dis. 2002;

14. Wynwood SJ, Craig SB, Graham GC, Blair BR, Burns MA, Weier SL, et al. The emergence of Leptospira borgpetersenii serovar Arborea as the dominant infecting serovar following the summer of natural disasters in Queensland, Australia 2011. Trop Biomed. 2014;

15. Dyah W, Anggun PD. Kontaminasi Leptospira Patogenik pada air Konsumsi di Pemukiman Kabupaten Demak. BALABA. 2015;11(6):89-96.

16. Badan Standarisasi Nasional. Cara uji suhu dengan termometer. In: Air dan Air Limbah. 2005. 
17. Badan Standarisasi Nasional. Cara uji derajat keasaman $(\mathrm{pH})$ dengan menggunakan $\mathrm{pH}$ meter. In: Air dan Air Limbah. 2004.

18. Trans Instrument. Operation Manual Digital Dissolved Oxigen Meter. 2015. p. 4-5.

19. Scola B La, Bui LTM, Baranton G, Khamis A, Raoult D. Partial rpoB gene sequencing for identification of Leptospira species. FEMS Microbiol Lett. 2006;

20. Cacciapuoti B, Ciceroni L, Maffei C, Stanislao F Di, Strusi P, Calegari L, et al. A waterborne outbreak of leptospirosis. Am J Epidemiol. 1987;

21. Levett PN. Leptospirosis. Clin Microbiol Rev [Internet]. 2001 Apr 1 [cited 2017 Jul 7];14(2):296-326. Available from: http://cmrasm. org/cgi/doi/10.1128/CMR.14.2.296-326.2001

22. Bina I. Analisis Faktor Risiko Kejadian Leptospirosis di Kabupaten Klaten, Provinsi Jawa Tengah. 2010.
23. Khairani-Bejo S, Bahaman a R, Zamri-Saad M, Mutalib a R. The survival of Leptospira interrogans serovar hardjo in the Malaysian environment. J Anim Vet Adv. 2004;

24. Smibert RM, Johnson RC. Spirochaetales, a review. Critical Reviews in Microbiology. 1973.

25. Tewodros F, Mekash A. Leptospirosis and It's Public Health Significance: A Review. Eur J Appl Sci. 2012;4(6):238-44.

26. Patty SI. Distribution Temperature, Salinity And Dissolved Oxygen In Waters Kema, North Sulawesi. J Ilm Platax. 2013;1(3):148-57.

27. Andre-Fontaine G, Aviat F, Thorin C. Waterborne Leptospirosis: Survival and Preservation of the Virulence of Pathogenic Leptospira spp. in Fresh Water. Curr Microbiol. 2015;

28. Faine S, Adler B, Bolin C, Perolat P (eds. Leptospira and Leptospirosis (2nd edition). Book, MedSci, Armadale, Aust. 1999; 
The Presence of Pathogenic Leptospira sp. in Water Bodies in Klaten District

ORIGINALITY REPORT

6

SIMILARITY INDEX
$5 \%$

INTERNET SOURCES
$4 \%$

PUBLICATIONS
$3 \%$

STUDENT PAPERS

\section{PRIMARY SOURCES}

1 www.remotemagazine.com

2 stm.sciencemag.org

Internet Source

3 doaj.org

4 Elves A. P. Maciel. "Household Transmission of Leptospira Infection in Urban Slum

Communities", PLoS Neglected Tropical

Diseases, 01/30/2008

Publication

5

C. Ensuncho-Hoyos, V Rodríguez-Rodríguez, A.

Pérez-Doria, O. Vergara, A Calderón-Rangel.

"Epidemiology behavior of leptospirosis in

Ciénaga de Oro, Córdoba (Colombia)", Tropical

Animal Health and Production, 2017

Publication 
Exclude quotes

On

Exclude matches

Off

Exclude bibliography

On 